\title{
Efisiensi Biaya dan Prospek Pengembangan Budidaya Tanaman Cabe Jawa
}

\author{
Ahmad Muzakki*, Soetriono, dan Sofia \\ Jurusan Agribisnis, Fakultas Pertanian, Universitas Jember
}

\begin{abstract}
Abstrak Penelitian ini bertujuan untuk menganalisis pendapatan petani terhadap budidaya, menganalisis efisiensi biaya, dan menganalisis prospek pengembangan budidaya cabe jawa. Lokasi penelitian ditentukan dengan menggunakan purposive method, yaitu di Desa Bagorejo Kecamatan Gumukmas Kabupaten Jember. Metode penelitian yang digunakan adalah metode deskriptif dan analitik. Metode pengambilan sampel menggunakan total sampling, untuk menjawab permasalahan pendapatan dan efisiensi biaya, sedangkan purposive sampling untuk menjawab permasalahan prospek pengembangan budidaya cabe jawa. Pengambilan data menggunakan metode wawancara dan observasi. Sedangkan analisa data dengan analisis pendapatan, $R / C$ ratio, dan analisis medan kekuatan (FFA). Hasil penelitian menunjukkan bahwa budidaya cabe jawa memiliki pendapatan yang menguntungkan karena penerimaan lebih besar dibandingkan dengan total biaya yang dikeluarkan, biaya budidaya cabe jawa tergolong efisien karena memiliki nilai $R / C$ ratio lebih dari satu. Prospek pengembangan budidaya cabe jawa tergolong baik dikarenakan total nilai faktor pendorong lebih besar dibandingkan faktor penghambat, sehingga budidaya cabe jawa baik untuk dilanjutkan.
\end{abstract}

Kata kunci: pendapatan; efisiensi biaya; prospek pengembangan; cabe jawa

\begin{abstract}
This study aims to analyse the income of farmers on the cultivation, analyse the efficiency of the cost, and analyse the prospects for the development of Javanese chilli cultivation in Bagorejo Village. The research location was determined by using the purposive method, namely in Bagorejo Village, Gumukmas Subdistrict, Jember Regency. The research used the descriptive and analytic method. The sampling method used total sampling to answer income problems and cost efficiencies, while purposive sampling was to answer the issue of the development prospects of Javanese chilli cultivation. The analysis used revenue analysis, $R / C$ ratio, and force field analysis (FFA). The results of the research showed that: Javanese chilli cultivation had a favourable income because the revenue was higher than the total cost of cultivation. The total cost of Javanese chilli cultivation was efficient because it had an $R / C$ ratio of more than one. The development prospects of Java chilli cultivation was good because the total value of the driving factors was higher than the inhibiting factors of Javanese chilli cultivation, so it was good to be developed.
\end{abstract}

Keywords: income; cost efficiency; development prospect; Java chilli

JEL Classification: $Q 12 ; D 24 ; O 12$ 


\section{PENDAHULUAN}

Tanaman cabe jawa memiliki peluang yang cerah untuk dikembangkan pada saat ini karena di Indonesia sendiri tidak hanya digunakan sebagai jamu akan tetapi juga digunakan sebagai bumbu masakan. Namun, budidaya tanaman cabe jawa di Indonesia masih belum intensif sehingga tidak ada perancanaan produksi yang tepat dan mengakibatkan tidak tercapainya target produksi. Rata-rata produksi cabe jamu kering hanya sekitar 1.48 ton/ha/tahun, padahal nilai itu jauh dari target produksi buah cabe jawa kering yakni sekitar 2.5 ton/ha/tahun (Djauhariya dkk dalam Pratidina dkk., 2015).

Salah satu wilayah yang memiliki peluang untuk membudidayakan cabe jawa adalah Jawa Timur. Tercatat pada Dinas Perkebunan Propinsi Jawa Timur (2013), luas areal tanaman cabe jawa di Propinsi Jawa Timur yakni memiliki luasan sekitar $4.211 \mathrm{Ha}$. Jumlah produksi buah cabe jawa dalam kondisi kering mencapai 1.329 ton. Sedangkan jumlah produktivitas buah cabe jawa mencapai $481 \mathrm{~kg} / \mathrm{ha}$. Angka penyebaran tanaman cabe jawa tersebar di beberapa wilayah di Jawa Timur diantaranya Madura, Lamongan, Banyuwangi, Jember, dan beberapa kabupaten lainnya (Evizal, 2013).

Dinas Tanaman Pangan, Hortikultura dan Perkebunan (2016) luas panen, produksi dan total produksi cabe jawa di Kabupaten Jember berdasakan kecamatan tahun 2016, Kecamatan Gumukmas merupakan kecamatan yang memiliki luas panen dan produksi tanaman cabe jawa yang tertinggi dibandingkan dengan kecamatan lain yang ada di Kabupaten Jember. Luas panen cabe jawa Kecamatan Gumukmas yakni sebesar $10.70 \mathrm{Ha}$, luas panen ini lebih tinggi dibandingkan dengan Kecamatan Wuluhan yakni sebesar $4.50 \mathrm{Ha}$. Produksi tanaman cabe jawa tertinggi berdasarkan kecamatan yang ada di Kabupaten Jember adalah Kecamatan Gumukmas dengan produksi tanaman sebesar $171.20 \mathrm{Kw}$, produksi tersebut lebih tinggi dibandingkan dengan total produksi Kecamatan Ambulu Hol dengan jumlah produksi sebesar $120.00 \mathrm{Kw}$.

Berdasarkan fenomena yang didapat dari survey pendahuluan, peneliti tertarik untuk membahas mengenai pendapatan yang diterima petani setelah perhitungan selisih penerimaan dikurangi total biaya yang dikeluarkan petani. Efisiensi biaya yang dikeluarkan petani pada kegiatan budidaya cabe jawa. Prospek pengembangan budidaya setelah mengidentifikasi faktor pendorong dan faktor penghambat kegiatan budidaya cabe jawa di Desa Bagorejo Kecamatan Gumukmas Kabupaten Jember.

\section{KAJIAN PUSTAKA}

Kegiatan budidaya cabe jawa dilakukan guna memberikan peningkatan pendapatan petani tingkat rumah tangga. Menurut Soetriono (2015) Pendapatan adalah total penerimaan (uang dan bukan uang) yang diterima oleh perorangan atau suatu rumah tangga selama periode tertentu. Pendapatan petani akan semakin tinggi apabila petani dapat menekan biaya variabel yang dikeluarkan untuk usahatani cabe jawa dan juga dapat meningkatkan produksi cabe jawa menjadi meningkat.

Pendapatan budidaya cabe jawa di Desa Bagorejo dilakukan selama setahun sehingga perlunya perhitungan penyusutan pada pendapatan cabe jawa. Menurut Ibrahim (1997) metode penyusutan rata-rata adalah salah satu cara yang dilakukan dalam penyusutan aset dengan cara rata-rata. Metode ini dikelompokkan menjadi 3 bagian, yakni metode garis lurus, metode jam kerja mesin, dan metode yang didasarkan pada jumlah produksi.

Komponen penting dari budidaya cabe jawa merupakan biaya usahatani yang dikeluarkan oleh petani selama kegiatan budidaya berlangsung. Menurut Hariyati 
(2007), ada beberapa konsep biaya total, yaitu: 1) biaya tetap total (total fixed cost) adalah biaya ini mewakili biaya-biaya untuk faktor-faktor produksi tetap. Biaya ini hanya mempunyai arti dalam jangka pendek, dimana faktor-faktor produksi yang dipergunakan merupakan faktor produksi tetap. Jumlah biaya ini tidak tergantung pada jumlah produk yang dihasilkan. 2) biaya variabel total (total variable cost) adalah biaya ini mewakili jumlah biaya-biaya untuk faktor-faktor produksi variabel. Biaya ini dapat berbentuk uang tunai, barang atau nilai uang jasa dan kerja yang sesungguhnya tidak dibayarkan. Besar biaya variabel total ditentukan oleh fungsi produksi atau oleh produk total dari proses produksi yang bersangkutan. 3) biaya total (total cost) adalah biaya total merupakan penjumlahan biaya tetap total dengan biaya variabel total. Tanpa memperhatikan apakah produksi berlangsung dengan kenaikan hasil bertambah atau berkurang, secara umum dapat dikatakan, bahwa semakin banyak produk yang dihasilkan semakin besar biaya total yang digunakan. Kegunaan biaya total ini adalah untuk menentukan pendapatan dari suatu usaha.

Kegiatan budidaya cabe jawa dilakukan dengan memaksimalkan keuntungan dan meminalkan biaya yang digunakan, sehingga perlunya perhitungan mengenai efisiensi biaya. Efisiensi biaya yaitu diindikasikan dengan biaya yang lebih rendah untuk jumlah output dan tingkat mutu tertentu. Efisiensi biaya produksi adalah hal yang penting bagi perusahaan-perusahaan jasa sekaligus pula perusahaan manufaktur. Perusahaan-perusahaan menentukan tujuan efisiensi biaya produksi dengan menggunakan tolak ukur yaitu metode pengevaluasian kinerja dengan melakukan perbandingan terhadap beberapa tingkat tolak ukur tertentu, biasanya suatu tingkat yang telah dicapai oleh perusahaan lain. Menurut Soekartawi (1995) menyatakan analisis R/C Rasio adalah singkatan dari Return Cost Ratio, atau dikenal sebagai perbandingan (nisbah) antar penerimaan dan biaya.

Pengembangan kegiatan budidaya tanaman cabe jawa di Desa Bagorejo dititiberatkan pada faktor-faktor pendorong dan penghambatnya. Berdasarkan kondisi di lapang, makan diperoleh beberapa faktor pendorong dan faktor penghambat dalam usaha pengembangan budidaya tanaman cabe jawa. Fungsi dari analisis medan kekuatan bertujuan untuj melihat semua kekuatan yang mendukung dan menentang keputusan sebuah penelitian. Menurut Sunarno (2008) mengatakan teknik implementasi analisis medan kekuatan dibagi menjadi 3 bagian diantaranya; 1) tingkat kinerja instansi; 2) identifikasi faktor pendorong dan penghambat; 3) penilaian faktor pendorong dan penghambat. Hasil dari analisis FFA akan didapatkan bagaimana prospek pengembangan dengan meminimalisir hambatan dengan mengedepankan faktor yang akan menjadi kekuatan kunci agar dapat memberikan dampak positif terhadap budidaya cabe jawa.

\section{METODE PENELITIAN}

Metode penentuan daerah penelitian yang ditentukan berdasarkan sampling secara sengaja. Daerah yang dijadikan sebagai tempat penelitian adalah Desa Bagorejo Kecamatan Gumukmas Kabupaten Jember, dengan pertimbangan bahwa Desa Bagorejo Kecamatan Gumukmas merupakan salah satu desa yang masyarakatnya banyak memanfaatkan lahan pekarangan untuk budidaya tanaman cabe jawa.

Metode penelitian yang digunakan adalah deskriptif dan analitis. Pengambilan sampel dilakukan dengan dua metode yakni total sampling untuk sampel masalah pendapatan dan efisien biaya yakni sebesar 40 orang serta purposive sampling untuk rumusan masalah mengenai prospek pengembangan yakni sebesar 5 orang. Metode pengambilan data dalam penelitian ini menggunakan observasi, wawancara, dan studi dokumenter. Untuk mengetahu pendapatan budidaya cabe jawa di Desa 
Bagorejo, digunakan analisis pendapatan dapat dituliskan dengan rumus sebagai berikut (Soekartawi dalam Soetriono dkk, 2014):

$$
\begin{aligned}
& Y=T R-T C \\
& T R=P \times Q \\
& T C=T F C+T V C
\end{aligned}
$$

$$
\begin{array}{ll}
\text { Keterangan: } \\
\text { Y } & =\text { Pendapatan } \\
\text { TR } & =\text { Penerimaan total } \\
\text { TVC } & =\text { Biaya variabel total } \\
\mathrm{P} & =\text { Harga per satuan } \\
\mathrm{Q} & =\text { Jumlah produksi } \\
\text { TFC } & =\text { Biaya tetap total }
\end{array}
$$

Kriteria pengambilan keputusan:

TR > TC, maka usahatani cabe jawa menguntungkan.

TR $<$ TC, maka usahatani cabe jawa merugikan.

$\mathrm{TR}=\mathrm{TC}$, maka usahatani cabe jawa mengalami impas (Break Event Point).

Kegiatan budidaya tanaman cabe jawa yang bersifat tahunan sehingga memerlukan perhitungan biaya penyusutan yang terjadi pada setiap tahunnya sehingga diperlukannnya metode penyusutan. Perhitungan jumlah penyusutan ratarata dapat dilakukan dengan menggunakan rumus sebagai berikut (Ibrahim, 1997):

$$
P=(B-S) / n
$$

Dimana:

$\mathrm{P} \quad=$ Jumlah penyusutan per tahun

$\mathrm{B} \quad=$ Harga beli aset (original cost)

$\mathrm{S} \quad=$ Nilai sisa (scrap value)

$\mathrm{n} \quad=$ Umur ekonomis aset.

Guna mengetahui apakah biaya yang dikeluarkan petani tergolong efisien atau tidak, dilakukan dengan menggunakan analisis R/C ratio. Menurut Soekartawi (1995) menyatakan analisis R/C Rasio adalah singkatan dari Return Cost Ratio, atau dikenal sebagai perbandingan (nisbah) anatar penerimaan dan biaya. Secara matematik, hal ini dapat dituliskan sebagai berikut:

$$
\begin{aligned}
& R=P y . Y \\
& C=F C+V C \\
& a=\{(P y . Y) /(F C+V C)\}
\end{aligned}
$$

Kriteria pengambilan keputusan:

a) R/C Ratio > 1, penggunaan biaya pada budidaya cabe jawa adalah efisien.

b) $\mathrm{R} / \mathrm{C}$ Ratio $<1$, penggunaan biaya pada budidaya cabe jawa adalah tidak efisien.

c) $\mathrm{R} / \mathrm{C}$ Ratio $=1$, penggunaan biaya pada budidaya cabe jawa adalah impas.

Untuk mengetahui prospek pengembangan budidaya cabe jawa di Desa Bagorejo menggunakan metode analisis force field. Berdasarkan hasil survey 
sementara mengenai kondisi lapang terdapat beberapa faktor pendorong dan faktor penghambat sebagai berikut:

Tabel 1. Faktor Penghambat dan Faktor Pendorong Budidaya Cabe Jawa di Desa Bagorejo Kecamatan Gumukmas Kabupeten Jember.

\begin{tabular}{|c|c|c|c|}
\hline No. & Faktor Pendorong & No. & Faktor Penghambat \\
\hline D1 & Adanya permintaan cabe jawa & $\mathrm{H} 1$ & Faktor cuaca yang berubah-ubah \\
\hline D2 & Pemanfaatan lahan pekarangan & $\mathrm{H} 2$ & Penyakit dan virus menyerang \\
\hline D3 & Budidaya cabe jawa menguntungkan & $\mathrm{H} 3$ & $\begin{array}{l}\text { Minimnya pengetahuan petani } \\
\text { tentang dosis pupuk }\end{array}$ \\
\hline D4 & Adanya asosiasi petani yang kondusif & $\mathrm{H} 4$ & Biaya tenaga kerja terlalu tinggi \\
\hline D5 & $\begin{array}{l}\text { Teknik budidaya cabe jawa yang } \\
\text { mudah }\end{array}$ & H5 & Keterbatasan informasi pasar \\
\hline
\end{tabular}

Sumber: data primer diolah 2017

\section{HASIL DAN PEMBAHASAN}

\section{Pendapatan Budidaya Cabe Jawa di Desa Bagorejo Kecamatan Gumukmas Kabupaten Jember}

Pendapatan budidaya cabe jawa di Desa Bagorejo dapat diketahui dengan cara menganalisis pendapatan. Hasil rata-rata pendapatan budidaya cabe jawa per pohon di Desa Bagorejo selama satu tahun budidaya dapat dilihat pada Tabel 2.

Tabel 2. Biaya Tetap, Biaya Variabel, Biaya Penyusutan, Total Biaya, Total Penerimaan, dan Pendapatan Budidaya Cabe Jawa di Desa Bagorejo pada tahun 2017

\begin{tabular}{llc}
\hline No & Uraian & Rata - rata Nilai (Rp/Tahun) \\
\hline 1. & Biaya Tetap (Rp/Tahun) & 2.406 .098 \\
2. & Biaya Variabel (Rp/Tahun) & 5.676 .353 \\
3. & Total Biaya (Rp/Tahun) & 8.082 .451 \\
4. & Total Penerimaan (Rp/Tahun) & 9.737 .278 \\
5. & Penerimaan (Rp/Ha/Tahun) & 5.915 .600 \\
6. & Pendapatan (Rp/Tahun) & 1.654 .827 \\
\hline
\end{tabular}

Sumber: data primer diolah 2017

Berdasarkan Tabel 2 biaya tetap yang dikeluarkan oleh petani selama melakukan kegiatan budidaya cabe jawa sebesar Rp.2.406.098/tahun. Biaya variabel yang digunakan petani dalam kegiatan budidaya cabe jawa sebesar Rp.5.676.353/tahun. Total biaya yang dikeluarkan petani dalam setahun budidaya cabe jawa sebesar Rp.8.082.451/tahun. Nilai penerimaan yang diterima petani dari penjualan cabe jawa sebesar Rp.9.737.278/tahun. Pendapatan perpohon cabe jawa yang diterima oleh petani Rp.5.915.600/Ha. Nilai tersebut didapatkan dari hasil pemetikan selama satu tahun dengan 18 kali masa pemetikan. Rata-rata pendapatan bersih petani cabe jawa di Desa Bagorejo dalam satu tahun budidaya sebesar Rp.1.654.827/tahun.

Beradasarkan dari hasil perhitungan yang dilakukan oleh pendapatan yang diterima oleh petani cabe jawa dapat dikatakan menguntungkan. Hal ini dikarenakan nilai penerimaan lebih besar dibandingkan dengan total biaya yang dikeluarkan oleh petani. Hal ini sejalan dengan hasil penelitian dari Sumantri dkk (2004) besarnya pendapatan yang diperoleh petani yaitu Rp.5.356.521,7 /pohon/tahun. Nilai rata-rata pendapatan yang diterima petani ini tergolong menguntungkan sehingga layak untuk dibudidayakan kedepannya. 


\section{Efisiensi Biaya Budidaya Tanaman Cabe Jawa di Desa Bagorejo Kecamatan Gumukmas Kabupaten Jember}

Perhitungan efisiensi biaya bertujuan mengetahui biaya yang dikeluarkan oleh petani untuk mendukung budidaya cabe jawa tergolong efisien atau tidak. Hasil perhitungan efisiensi biaya dapat dilihat pada Tabel 3.

Tabel 3. Total Penerimaan, Total Biaya dan R/C Ratio Budidaya Cabe Jawa di Desa Bagorejo dalam periode satu tahun budidaya

\begin{tabular}{ccrr}
\hline Jenis Lahan & Penerimaan (Rp) & Total Biaya (Rp) & \multicolumn{2}{c}{ R/C Ratio } \\
\hline Lahan Pekarangan & 9.737 .278 & 8.082 .451 & 1,20 \\
\hline Sumber: data primer diolah tahun 2017 & &
\end{tabular}

Tabel 3 dapat diketahui rata-rata total penerimaan (TR) yang dapat diterima oleh petani dalam melakukan kegiatan budidaya tanaman cabe jawa dengan memanfaatkan lahan pekarangan adalah sebesar Rp.9.737.278/tahun. Nilai tersebut didapatkan dari hasil perhitungan rata-rata produksi buah cabe jawa kering dalam satu tahun dikalikan rata-rata harga jual buah cabe jawa. Rata-rata harga jual tertinggi yang diterima oleh petani sebesar Rp. 59.000 dan rata-rata harga terendah yang diterima oleh petani adalah sebesar Rp.31.000. Rata-rata total biaya yang dikeluarkan petani untuk mengembangkan budidaya cabe jawa di Desa Bagorejo adalah sebesar Rp.8.082.451/tahun. Rata-rata total biaya tersebut terdiri dari ratarata total biaya tetap sebesar Rp.2.406.098/tahun dan total biaya variabel yang dikeluarkan petani sebesar Rp.5.676.353/tahun.

Rata-rata nilai $\mathrm{R} / \mathrm{C}$ ratio sebesar 1,20 berarti bahwa setiap penggunaan $\mathrm{Rp} .1$ biaya produksi maka dapat menghasilkan rata-rata penerimaan sebesar Rp.1,20 yang berarti kegiatan budidaya cabe jawa memperoleh keuntungan sebesar 0,20 untuk penggunaan Rp.1 rata-rata biaya produksi yang dikeluarkan petani. Hal ini sejalan dengan penelitian dari Maryadi dkk (2016) nilai R/C ratio atas biaya tunai adalah 2,1 yang artinya setiap Rp.1 biaya tunai yang dikeluarkan oleh petani akan menghasilkan penerimaan Rp.2,1. Apabila memasukkan biaya yang diperhitungkan dalam komponen biaya total, maka nilai $\mathrm{R} / \mathrm{C}$ ratio menjadi 1,8 yang berarti setiap $\mathrm{Rp} .1$ biaya yang dikeluarkan akan memperoleh penerimaan sebesar Rp.1,8. Nilai R/C ratio yang lebih dari satu menunjukkan bahwa usahatani lada di Kabupaten Bangka Tengah masih menguntungkan.

\section{Prospek Pengembangan Budidaya Cabe Jawa di di Desa Bagorejo Kecamatan Gumukmas Kabupaten Jember}

Peneliti melakukan penilian pada faktor pendorong yang didapatkan dari hasil wawancara dengan responden yang telah ditentukan 5 faktor pendorong dan 5 faktor penghambat. Faktor-faktor tersebut didapatkan dari hasil fenomena yang ada di lapang dan berdasarkan penggabungan hasil dari permasalahan pendapatan dan efisiensi biaya kegiatan budidaya cabe jawa. Faktor-faktor tersebut dapat dilihat pada Tabel 4 mengenai hasil evaluasi faktor pendorong.

Tabel 4 menunjukkan bahwa nilai rata-rata TNB terbesar menunjukkan FKK tertinggi pada faktor pendorong adalah D1 yaitu adanya permintaan cabe jawa dengan nilai TNB 1,88. Adanya permintaan cabe jawa menjadi faktor yang sangat berpengaruh terhadap kegiatan budidaya cabe jawa di Desa Bagorejo. Kualitas hasil panen yang baik akan mendorong harga jual cabe jawa akan meningkat sehingga membantu petani dalam memenuhi kebutuhan hidupnya. Penilaian evaluasi faktor penghambat dapat dilihat pada Tabel 5.

Tabel 5 menunujukkan bahwa nilai rata-rata TNB terbesar menunjukkan FKK tertinggi pada faktor penghambat adalah $\mathrm{H} 2$ yaitu penyakit dan virus menyerang 
dengan nilai TNB 2,09. Serangan penyakit dan virus mengakibatkan menurunnya semangat petani melakukan kegiatan budidaya cabe jawa. Hal ini dikarenakan bentuk serangan penyakit dan virus menyebabkan kerusakan pada tanaman yang berakhir dengan kematian pada tanaman cabe jawa di Desa Bagorejo.

Tabel 4. Evaluasi Faktor Pendorong Prospek Pengambangan Budidaya Cabe Jawa di Desa Bagorejo

\begin{tabular}{clllllll}
\hline No & Faktor Pendorong & BF & NU & NBD & NBK & TNB & FKK \\
\hline D1 & Adanya permintaan cabe jawa & 0,26 & 4,2 & 1,08 & 0,81 & 1,88 & $1^{*}$ \\
D2 & Pemanfaatan lahan pekarangan & 0,21 & 3,4 & 0,83 & 0,51 & 1,34 & 3 \\
D3 & Budidaya cabe jawa menguntungkan & 0,17 & 2,8 & 0,51 & 0,52 & 1,03 & 4 \\
D4 & Adanya asosiasi petani yang kondusif & 0,12 & 2 & 0,27 & 0,28 & 0,55 & 5 \\
D5 & $\begin{array}{l}\text { Teknik budidaya cabe jawa yang } \\
\text { mudah }\end{array}$ & 0,24 & 4 & 0,83 & 0,60 & 1,43 & 2 \\
\hline & Total & $\mathbf{1}$ & $\mathbf{1 6 , 4}$ & & & $\mathbf{6 , 2 3}$ & \\
\hline
\end{tabular}

Sumber: data olahan primer, 2017

Keterangan:

* $\quad=$ Prioritas $(\mathrm{FKK})$

$\mathrm{BF} \quad=$ Bobot Faktor

$\mathrm{NU} \quad=$ Nilai Urgensi

NBD = Nilai Bobot Dukungan

NBK = Nilai Bobot Keterkaitan

TNB $=$ Total Nilai Bobot

FKK = Faktor Kunci Keberhasilan

Tabel 5. Evaluasi Faktor Penghambat Prospek Pengambangan Budidaya Cabe Jawa di Desa Bagorejo

\begin{tabular}{clllllll}
\hline No & Faktor Pendorong & BF & NU & NBD & NBK & TNB & FKK \\
\hline H1 & Faktor cuaca berubah-ubah & 0,26 & 4 & 1,13 & 0,60 & 1,73 & 2 \\
H2 & $\begin{array}{l}\text { Penyakit dan virus menyerang } \\
\text { H3 }\end{array}$ & 0,31 & 4,8 & 1,29 & 0,79 & 2,09 & $1^{*}$ \\
& $\begin{array}{l}\text { Minimnya pengetahuan petani tentang } \\
\text { dosis pupuk }\end{array}$ & 0,19 & 3 & 0,54 & 0,45 & 0,99 & 3 \\
H4 & $\begin{array}{l}\text { Biaya tenaga kerja terlalu tinggi } \\
\text { Keterbatasan mengenai informasi }\end{array}$ & 0,09 & 1,4 & 0,16 & 0,16 & 0,32 & 5 \\
& 0,15 & 2,4 & 0,37 & 0,41 & 0,78 & 4 \\
\hline & \multicolumn{1}{c}{ Total } & $\mathbf{1}$ & $\mathbf{1 5 , 6}$ & & & $\mathbf{5 , 9 1}$ & \\
\hline
\end{tabular}

Sumber: data olahan primer, 2017

Keterangan:

* = Prioritas (FKK)

$\mathrm{BF} \quad=$ Bobot Faktor

$\mathrm{NU} \quad=$ Nilai Urgensi

NBD = Nilai Bobot Dukungan

NBK = Nilai Bobot Keterkaitan

TNB $=$ Total Nilai Bobot

FKK = Faktor Kunci Keberhasilan

Nilai evaluasi faktor pendorong dan faktor penghambat dapat dilihat dalam bentuk grafik medan kekuatan. Hasil nilai evaluasi grafik didapatkan dari perhitungan Total Nilai Bobot (TNB) faktor pendorong dan faktor penghambat yang ada di lokasi. Berikut gambar grafik medan kekuatan dari faktor pendorong dan faktor penghambat prospek pengembangan budidaya cabe jawa di Desa Bagorejo pada Gambar 1. 


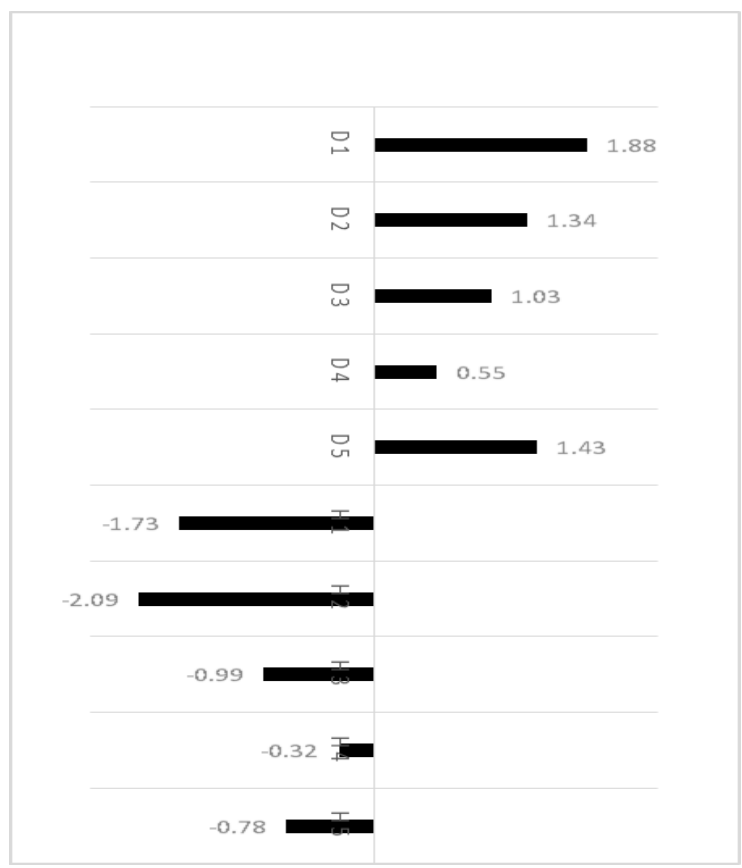

Gambar 1. Medan Kekuatan pada Prospek Pengembangan Budidaya Tanaman Cabe Jawa di Desa Bagorejo

Berdasarkan Gambar 1 panjang anak panah menjelaskan besarnya TNB dari setiap faktor sedangkan arah anak panah merupakan tarik-menarik antara faktor pendorong dan faktor penghambat. Total nilai TNB faktor pendorong tertinggi yakni sebesar 6,23, sedangakan total nilai TNB faktor penghambat yaitu sebesar 5,91. Hal ini menjelaskan bahwa total nilai TNB faktor pendorong lebih tinggi dibandingkan dengan total nilai TNB faktor penghambat yang berarti petani di Desa Bagorejo dapat mengoptimalkan pengembangan kegiatan budidaya cabe jawa.

Penentuan strategi secara umum dapat dipertimbangkan melalui penggabungan faktor pendorong dan faktor penghambat yang mempengaruhi kegiatan pengembangan budidaya cabe jawa di Desa Bagorejo. Mengoptimalkan keberlangsungan kegiatan budidaya cabe jawa adalah strategi umum yang dapat mempertahankan faktor pendorong dan meminimalisir faktor penghambat. Pengaplikasian strategi tersebut kepada para petani di Desa Bagorejo dapat dilakukan dengan meminta bantuan para Petugas Penyuluh Lapang (PPL) yang bekerja sama dengan asosiasi cabe jawa. Peran PPL dalam pengaplikasian strategi dilakukan dengan cara: 1) melakukan peninjauan budidaya cabe jawa di golongan petani, 2) memberikan informasi mengenai tata cara budidaya cabe jawa yang baik, 3) melakukan pelatihan penanggulangan serangan penyakit dan virus pada tanaman cabe jawa.

\section{SIMPULAN DAN SARAN}

\section{Simpulan}

Budidaya cabe jawa di Desa Bagorejo memiliki penerimaan yang lebih besar dibandingkan dengan total biaya yang dikeluarkan. Hal ini menandakan hasil dari kegiatan budidaya cabe jawa yang diterima oleh petani tergolong menguntungkan. Hal ini juga serupa pada hasil perhitungan efisiensi biaya dari total biaya yang dikeluarkan petani untuk mendukung kegiatan budidaya tanaman cabe jawa tergolong efisien. Keberlanjutan budidaya tanaman cabe jawa didukung dari hasil analisa prospek pengembangan menggunakan analisis medan kekuatan (FFA) 
menyatakan bahwa faktor pendorong yang berpengaruh adalah tingginya permintaan budidaya cabe jawa (D1) serta faktor penghambat yang berpengaruh adalah penyakit dan virus yang menyerang $(\mathrm{H} 2)$ tanaman cabe jawa. Penentuan pengaruh tersebut terhadap prospek pengembangan menggunakanan dasar Faktor Kunci Keberhasilan (FKK).

\section{Saran}

Adanya permintaan cabe jawa harus dipertahankan oleh petani dengan menjaga kualitas dan kuantitas cabe jawa mulai dari tanam sampai panen. Petani harus memperhatikan pemupukan cabe jawa dengan membuat larikan sekeliling areal pohon cabe jawa agar proses pemupukan dapat memberikan nutrisi bagi tanaman cabe jawa. Sedangkan faktor penghambat kegiatan budidaya adalah serangan penyakit dan virus pada tanaman cabe jawa. Tindakan untuk meminimalisir hambatan tersebut adalah memperhatikan gejala serta bentuk serangan yang diakibatkan oleh penyakit dan virus yang menyerang agar saat melakukan pengobatan dapat berjalan dengan efektif.

\section{DAFTAR PUSTAKA}

Evizal, R. 2013. Status Fitofarmaka dan Perkembangan Agroteknologi Cabe Jawa (Piper Retrofractum Vahl.). Jurnal Agrotropika 18(1): 34-40.

Hariyati, Y. 2007. Ekonomi Mikro (Pendekatan Matematis dan Grafis). Jember: CSS.

Ibrahim, Y. 1997. Studi Kelayakan Bisnis. Jakarta: PT Rineka Cipta.

Maryadi, S. Atang, dan A. Ivanovich. 2016. Analisis Usaha Tani Lada dan Arahan Pengembangannya di Kabupaten Bangka Tengah. TATALOKA 18(2): 76-84. https://doi.org/10.14710/tataloka.18.2.76-84

Pratidina, N.V.A., A. Syamsunihar, dan S. Winarso. 2015. Pertumbuhan Bibit Cabe Jawa (Piper Retrofractum Vahl.) Sebagai Respon Terhadap Dosis dan Jenis Pupuk Nitrogen. Berkala IImu Pertanian 10(10): 1-5.

Soekartawi. 1995. Analisis Usahatani. Jakarta: Universitas Indonesia.

Soetriono, E. Solihahani, F.A. Zulan, N. Inayatin, N. Susanti, N. Susanti, dan Q. Zuniana. 2014. Agribisnis Tembakau Besuki Na-Oogst: Tinjauan Ekonomi Pertanian. Malang: Surya Pena Gemilang.

Soetriono. 2015. Daya Saing Kopi Robusta. Malang: Surya Pena Gemilang.

Sumantri, B., S.P. Basuki, dan I. Mery. 2004. Analisis Kelayakan Finansial Usahatani Lada (Piper nigrum, L) di Desa Kunduran Kecamatan Ulu Musi Kabupaten Lahat Sumatera Selatan. Jurnal IImu-ilmu Pertanian Indonesia 6(1): 32-42.

Sunarno. 2008. Teknik-teknik Analisis Manajemen. Jakarta: Lembaga Administrasi Negara. 